\title{
Tobacco smoking and body composition in persons living with HIV/AIDS
}

\author{
Tagabismo e composição corporal \\ em pessoas vivendo com HIV/AIDS
}

Lúcia Helena Gonzales Real (https://orcid.org/0000-0002-3321-3673) ${ }^{1}$

Fernanda Pedrotti Moreira (https://orcid.org/0000-0002-3672-7231) ${ }^{1}$

Maria Cristina Gonzalez (https://orcid.org/0000-0002-3901-8182) ${ }^{1}$

Karen Jansen (https://orcid.org/0000-0003-3494-8070) ${ }^{1}$

${ }^{1}$ Programa de PósGraduação em Saúde e

Comportamento, Faculdade

de Medicina, Universidade

Católica de Pelotas. Avenida

Duque de Caxias 250,

Fragata. 96030-000 Pelotas

RS Brasil.

luciagreal@gmail.com

\begin{abstract}
This study aimed to assess the association between tobacco smoking and body composition in patients with HIV/AIDS in combination antiretroviral therapy (cART). This is a crosssectional study with people of HIV followed in specialized care service for HIV patients located in the South of Brazil. The Alcohol, Smoking and Substance Involvement Screening Test (ASSIST) was used to assess smoking and other psychoactive substance use. Body mass index (BMI) was calculated as the ratio of body weight (in kilograms) to squared height (in meters). Patients also had their body composition evaluated with a multi-frequency bioelectrical impedance (Bodystat ${ }^{\circledR}$ Quadscan 4000, RU) to estimate skeletal muscle index (SMI). In total, 320 subjects were included in the study. The prevalence of smoking was $54.7 \%$. Tobacco smoking was associated with malnutrition, lower body mass index scores, and lower skeletal muscle mass index. It is concluded that there is a high prevalence of smoking among patients with HIV/AIDS and that this behavior is associated with worse body composition. Thus, it is suggested to implement strategies to support smoking cessation among people with HIV/AIDS. Key words Smoking, HIV, AIDS, Body composition
\end{abstract}

Resumo O objetivo deste estudo foi avaliar a relação entre tabagismo e composição corporal em pacientes com HIV/AIDS em terapia antirretroviral combinada (TARVc). Trata-se de um estudo transversal com portadores de HIV acompanhados em um serviço de atendimento especializado localizado no Sul do Brasil. O instrumento Alcohol, Smoking and Substance Involvement Screening Test (ASSIST) foi utilizado para avaliar o uso de tabaco e outras substâncias psicoativas. $O$ indice de massa corporal (IMC) foi calculado como a razão do peso corporal (em quilogramas) pela altura ao quadrado (em metros). Os pacientes também tiveram sua composição corporal avaliada com uma impedância bioelétrica de múltiplas frequências (Bodystat ${ }^{\circledR}$ Quadscan 4000, RU) a fim de estimar o indice de massa muscular esquelética. No total, 320 sujeitos foram incluídos no estudo. A prevalência de tabagismo foi de 54,7\%. O tabagismo foi associado à desnutrição, menores escores do indice de massa corporal e menor indice de massa muscular esquelética. Conclui-se que há uma alta prevalência de tabagismo entre pacientes com HIV/AIDS e que esse comportamento está associado a pior composição corporal. Assim, sugere-se a implementação de estratégias de apoio à cessação do tabagismo entre pessoas com HIV/ AIDS.

Palavras-chave Tabagismo, HIV, AIDS, Composição corporal 


\section{Introduction}

The American Centers for Disease Control and Prevention (CDC) estimates that approximately $50 \%$ of people living with HIV/AIDS smoke and that $75 \%$ smoked at some point in their lives, contrasting with the prevalence of $15 \%$ among the general American population ${ }^{1}$. In Brazil, data from the National Health Research show that $14.7 \%$ of adult Brazilians smoke, while among patients with HIV/AIDS, approximately $30 \%$ are smokers $^{2,3}$. It has been estimated that the number of smokers living with HIV is 2 or 3 times higher than the general population ${ }^{1}$. According to the World Health Organization (WHO), regardless of HIV/AIDS infection, smoking is the leading preventable risk factor that contributes to significant morbidity and mortality in the general population ${ }^{1}$. A study conducted by Helleberg et al. (2013) show that patients with HIV/AIDS smokers lose more life-years to smoking than to $\mathrm{HIV}^{4}$.

Studies have shown that patients living with HIV/AIDS have lived long after the introduction of the combination antiretroviral therapy (cART) in $1990^{1}$. However, it has also been observed that although living longer, these individuals present a higher prevalence of early onset multiple comorbidities, including infectious diseases, such as hepatitis, and chronic diseases, hypertension, and diabetes, compared to non-infected individuals $^{5,6}$. A study conducted in Italy has shown that the prevalence of chronic diseases in HIV subjects aged between 41 and 50 years old is comparable to the prevalence of these comorbidities in seronegative individuals between 51 and 60 years of age, supporting the need for earlier screening for chronic diseases in HIV-infected patients ${ }^{7}$. Indeed, smoking may be associated with these high rates of comorbidities among individuals with HIV/AIDS 8 .

Another process that is considered important among individuals with HIV/AIDS using cART is the progressive reduction of muscle mass or sarcopenia ${ }^{9-11}$. Sarcopenia is defined as the generalized loss of skeletal muscle mass, accompanied by reduced strength and functional capacity, and is considered a risk factor for incapacity and mortality in HIV-infected patients ${ }^{10}$. However, studies of body composition in HIV-infected patients have focused primarily on lipodystrophy $^{12,13}$, while skeletal muscle mass has been poorly explored. Recent research has shown that HIV-infected patients had an approximately five times higher risk for sarcopenia compared to the risk of the controls, suggesting "accelerated aging syndrome" in HIV-infected patients ${ }^{10}$.

Lee et al., studying the association between lifestyle and sarcopenia in HIV-infected patients, observed that smokers had lower appendicular skeletal muscle mass than individuals who never smoked ${ }^{14}$. It is known that low skeletal muscle mass is central to the definition of sarcopenia. In addition to tobacco, low levels of physical activity and malnutrition are also associated with body composition alterations. Malnutrition is common in advanced stages of the disease, caused by inadequate food intake, malabsorption of nutrients caused by cART, and increased energy needs and metabolic changes, promoting a negative energy balance ${ }^{15,16}$. Previous studies have shown that malnutrition is an independent predictor for survival in HIV-infected patients, suggesting that when present at the onset of cART, malnutrition offers a weak immune response and an impaired treatment response ${ }^{17,18}$. Besides, even in normal-weight subjects, HIV infection and cART are associated with metabolic alterations, including fat redistribution and increased cardiovascular disease risk, factors aggravated by smoking ${ }^{18}$.

To the best of our knowledge, studies assessing smoking and skeletal muscle mass loss or sarcopenia in patients with HIV/AIDS have not yet been developed. Besides, data from Brazilian individuals with HIV/AIDS are minimal. Thus, this paper aims to assess the association between tobacco smoking and body composition in patients with HIV/AIDS.

\section{Method}

This is a cross-sectional study with patients of HIV receiving antiretroviral therapy (ART). The patients who were invited to participate in this study have been under treatment in specialized care service for HIV/AIDS patients located in the south of Brazil within the period from May 2016 to June 2017. The inclusion criteria were patients who had been diagnosed with HIV/AIDS and using cART for at least one year and who were 18 years or older. Patients who were pregnant or institutionalized (homeless patients, patients in prison, or living in therapeutic clinics) were excluded. The study was part of a larger one entitled, "HIV/AIDS: Adherence and Maintenance of Antiretroviral Treatment," which was approved by the Ethics Committee of the Universidade Católica de Pelotas. 
Initially, patients answered a questionnaire which contained questions about the social/demographic characteristic of the individuals: sex (male/female), skin color (non-white/white), economic level through Associação Brasileira de Empresas de Pesquisa (ABEP) (high/middle/ low), age (years old), and education level (years). For ABEP, we classified in three categories, because low prevalence in the upper class, and there were no individuals in the lower level. For tobacco use evaluation, The Alcohol, Smoking, and Substance Involvement Screening Test (ASSIST), developed by the World Health Organization (WHO) was used, as well as a cut-off of 4 points for substance abuse/dependence validated for the Brazilian population by Henrique et al. $(2004)^{19}$. Time of HIV diagnosis (years), time use of ART (years), detectable viral load HIV RNA in plasma (viral load) of the last 30 days [measured by the Abbott Real-time assay ( $<40$ copies/ $\mathrm{mL}$ )], presence of diabetes and hypertension, and polypharmacy (use of 5 or more chronic medications) were collected from the medical records.

Anthropometric data (weight and height) were also collected. Height was measured without shoes to the nearest $0.1 \mathrm{~cm}$. Weight was measured in kilograms to the nearest $0.1 \mathrm{~kg}$. Body mass index (BMI) was calculated as the ratio of body weight (in kilograms) to squared height (in meters) ${ }^{20}$. We considered our measure of malnutrition as BMI below $18.5 \mathrm{~kg} / \mathrm{m}^{2}$. Patients also had their body composition evaluated with a multi-frequency bioelectrical impedance (Bodystat ${ }^{\circledR}$ Quadscan 4000, RU) to estimate skeletal muscle index (SMI ${ }^{21}$. SMI is expressed as a percentage. Sarcopenia was considered when SMI $<10.75 \mathrm{~kg} / \mathrm{m}^{2}$ (men) and $<6.75 \mathrm{~kg} / \mathrm{m}^{2}$ (women) $)^{22}$.

The characteristics of the patients were described as percentages, or median and interquartile range, as appropriate. Pearson's Chi-square test was used to study the associations between categorical variables, and where applicable, the Mann-Whitney test was used. Linear or Poisson regression was performed to adjust the variables with $\mathrm{p}<0.20$ for smoking in the crude analysis, as appropriate. All analyses were performed using SPSS 21.0 for Windows. The significance limits were set at $\mathrm{p}<0.05$.

\section{Results}

In total, 320 patients with HIV/AIDS (179 females and 141 males), completed clinical evaluations, and 262 underwent a bioelectrical im- pedance analysis (BIA); 58 patients refused to participate in the biometric assessment. Table 1 shows the sample characteristics.

The smoking prevalence was $54.7 \%$. Patients with HIV/AIDS who smoked were significantly younger $(42.49 \pm 10.81)(\mathrm{p}<0.001)$, non-whites (63.4\%, $\mathrm{p}=0.015)$, males $(61.7 \%, \mathrm{p}=0.034)$, patients from lower economic level $(62.9 \%$, $\mathrm{p}=0.010$ ), and those with a lower level of education $(62.9 \%, \mathrm{p}=0.010)$ (Table 1$)$.

Smokers had a lower prevalence of chronic diseases $(60.0 \%)$ as compared to non-smokers (74.5\%; $\mathrm{p}=0.009$ ) (Table 2). Regarding BMI, smokers showed median scores of 24.3 (21.5; 27.0) while non-smokers showed 26.7 (23.8; $30.3) \mathrm{kg} / \mathrm{m}^{2}$. Thus smoking was associated with a lower BMI score $(\mathrm{p}<0.001)$. Smokers had a higher prevalence of malnutrition $(7.4 \%$; $\mathrm{p}<0.001)$, and sarcopenia $(4.6 \% ; \mathrm{p}=0.045)$ as compared to non-smokers. Lower skeletal muscle mass index was verified among the smokers than non-smokers $(p=0.038)$. Smoking was not related to adherence to ART, detectable viral load, or even antiretroviral therapy regimens (Table 2). Moreover, patients with HIV/AIDS who smoked and had hypertension or diabetes were significantly older. The mean age in hypertensives smokers was $49.48 \pm 8.92$ years, while in non-hypertensives was $40.29 \pm 10.43$ years $(\mathrm{p}<0.001)$. In this same way, diabetics smokers the mean age was $53.09 \pm 11.11$ years, while in non-diabetics was $41.78 \pm 10.45$ years $(\mathrm{p}=0.007)$ (data not shown).

Table 3 shows hypertension and diabetes, and body composition among the smokers, adjusted for the sociodemographic characteristic (sex, skin color, age, economic level, and level of education), time of HIV diagnosis, detectable viral load and antiretroviral therapy regiments. In this sample, the presence of smoking was shown to be a protective factor for diabetes $(\mathrm{p}=0.042)$. However, smoking is associated with a higher probability of malnutrition $(\mathrm{p}=0.023)$ and lower BMI score $(\mathrm{p}<0.001)$. In addition, a trend was observed for the association between smoking and lower skeletal muscle mass index $(\mathrm{p}=0.057)$.

\section{Discussion}

In this study, we confirmed a high prevalence of smokers in HIV patients; nearly half of these patients smoked, in corroboration with data from other studies conducted in other countries ${ }^{23-25}$. However, our results showed an even higher prevalence of smoking compared to similar 
Table 1, Demographic characteristics associated with smoking among patients with HIV/AIDS at specialized care service,

\begin{tabular}{|c|c|c|c|c|}
\hline Demographic and clinical characteristics & Total sample & Non-smoker & Smoker & p-value \\
\hline $\operatorname{Sex}^{1}$ & & & & 0,034 \\
\hline Female & $179(55,9)$ & $91(50,8)$ & $88(49,2)$ & \\
\hline Male & $141(44,1)$ & $54(38,3)$ & $87(61,7)$ & \\
\hline Skin color ${ }^{1^{*}}$ & & & & 0,021 \\
\hline Non-white & $123(38,6)$ & $45(36,6)$ & $78(63,4)$ & \\
\hline White & $196(61,4)$ & $99(50,5)$ & $97(49,5)$ & \\
\hline Economic level $^{1}$ & & & & 0,010 \\
\hline High & $42(13,2)$ & $24(57,1)$ & $18(42,9)$ & \\
\hline Middle & $151(47,7)$ & $75(49,7)$ & $76(50,3)$ & \\
\hline Low & $124(39,1)$ & $46(37,1)$ & $78(62,9)$ & \\
\hline Age (years) ${ }^{2}$ & $44,84 \pm 12,21$ & $47,67 \pm 13,21$ & $42,49 \pm 10,81$ & $<0,001$ \\
\hline Education level (years) ${ }^{3}$ & $6,5(4,0 ; 11,0)$ & $8,0(5,0 ; 11,0)$ & $6(4,0 ; 10,0)$ & 0,028 \\
\hline Total & $320(100)$ & $145(45,3)$ & $175(54,7)$ & --- \\
\hline
\end{tabular}

Table 2. Clinical outcomes and body composition associated with smoking among patients with HIV/AIDS at specialized care service.

\begin{tabular}{|c|c|c|c|c|}
\hline $\begin{array}{c}\text { Clinical characteristics and body } \\
\text { composition }\end{array}$ & Total sample & Non-smoker & Smoker & p-value \\
\hline Time of HIV diagnosis (years) ${ }^{1}$ & $9,0(4,0 ; 15,0)$ & $8,0(4,0 ; 14,0)$ & $10,0(5,0 ; 16,0)$ & 0,049 \\
\hline Time of ART use (years) ${ }^{1}$ & $8,0(4,0 ; 12,7)$ & $7(4,0 ; 13,0)$ & $8(3,0 ; 12,0)$ & 0,531 \\
\hline Antiretroviral Therapy Regiments ${ }^{2}$ & & & & 0,200 \\
\hline $\mathrm{EFZ}+\mathrm{TDF}+3 \mathrm{~T}$ & $105(32,8)$ & $39(26,9)$ & $66(37,7)$ & \\
\hline $\mathrm{EFZ}+\mathrm{AZT}+3 \mathrm{TC}$ & $66(20,6)$ & $29(20,0)$ & $37(21,1)$ & \\
\hline $\mathrm{LPV} / \mathrm{r}+\mathrm{AZT}+3 \mathrm{TC}$ & $34(10,6)$ & $14(9,7)$ & $20(11,4)$ & \\
\hline $\mathrm{ATV} / \mathrm{r}+\mathrm{AZT}+3 \mathrm{TC}$ & $18(5,6)$ & $9(6,2)$ & $9(5,1)$ & \\
\hline $\mathrm{ATV} / \mathrm{r}+\mathrm{TDF}+3 \mathrm{TC}$ & $36(11,3)$ & $21(14,5)$ & $15(8,6)$ & \\
\hline $\mathrm{LPV} / \mathrm{r}+\mathrm{TDF}+3 \mathrm{TC}$ & $36(11,3)$ & $18(12,4)$ & $18(10,3)$ & \\
\hline Others drugs & $25(7,8)$ & $15(10,3)$ & $10(40,0)$ & \\
\hline Detectable viral load ${ }^{2}$ & $60(18,8)$ & $22(15,2)$ & $38(21,7)$ & 0,177 \\
\hline Diabetes $^{2}$ & $33(10,3)$ & $22(15,2)$ & $11(6,3)$ & 0,009 \\
\hline Hypertension $^{2}$ & $91(28,4)$ & $49(33,8)$ & $42(24,0)$ & 0,050 \\
\hline Malnutrition $^{2}$ & $15(4,8)$ & $2(1,4)$ & $13(7,4)$ & $<0,001$ \\
\hline Body mass index ${ }^{1}$ & $25,3(22,8 ; 28,7)$ & $26,7(23,8 ; 30,4)$ & $24,3(21,5 ; 27,0)$ & $<0,001$ \\
\hline Sarcopenia $^{2}$ & $9(3,4)$ & $1(0,7)$ & $8(4,6)$ & 0,045 \\
\hline Skeletal muscle mass index ${ }^{1}$ & $11,3(10,3 ; 12,5)$ & $11,5(10,4 ; 12,9)$ & $11,1(10,2 ; 12,1)$ & 0,038 \\
\hline
\end{tabular}

${ }^{1}$ Mann-Whitney test, values shown by median and interquartile range; ${ }^{2}$ Chi-square test, values shown by absolute and relative frequencies.

Source: The authors.

studies in different regions of Brazil, where the prevalence found was approximately $30 \%{ }^{2}$. On the other hand, the sociodemographic characteristics of the smoking HIV/AIDS population from this study followed the pattern of the results from other studies and revealed that young non-white adults, from lower social classes and with lower levels of education have a higher probability of being smokers ${ }^{2,23-25}$.

Patients with HIV/AIDS are undergoing a higher prevalence of comorbidities, and smoking may confer an increased risk of developing 
Table 3. Chronic diseases and body composition among the smokers adjusted for the sociodemographic characteristic (sex, skin color, economic level, and age), time of HIV diagnosis, detectable viral load, and antiretroviral therapy regiments.

\begin{tabular}{llc}
\hline \multicolumn{1}{c}{ Clinical outcomes and body composition } & $\begin{array}{c}\text { B (regression coefficient) / RP (prevalence } \\
\text { ratio) and 95\% confidence interval }\end{array}$ & p-value \\
\hline Diabetes $^{1}$ & $0,49(0,25 ; 0,98)$ & 0,042 \\
Hypertension $^{1}$ & $0,74(0,53 ; 1,06)$ & 0,096 \\
Malnutrition $^{1}$ & $3,64(1,19 ; 11,15)$ & 0,023 \\
Body mass index $^{2}$ & $-2,67(-3,77 ;-1,57)$ & $<0,001$ \\
Sarcopenia $^{1}$ & $3,04(0,64 ; 14,45)$ & 0,161 \\
Skeletal muscle mass index $^{2}$ & $-0,31(-0,63 ;-0,01)$ & 0,057 \\
\hline
\end{tabular}

${ }^{1}$ Adjusted analysis by Poisson regression; ${ }^{2}$ Adjusted analysis by Linear regression.

Source: The authors.

chronic diseases leading to substantial morbidity and mortality among HIV-positive individuals $s^{4,7}$. Since people with HIV have higher survival, there is now a concern with other chronic conditions, two of them hypertension and diabetes, which are also public health problems due to the economic impact social and health system, reflecting the quality of the and life expectancy of individuals. In our study, it was shown that smoking was related to a lower prevalence of hypertension and diabetes. However, it seems that age is an important factor to be considered. We found that mean age was higher among hypertensives smokers than non-hypertensives, as well as among diabetics smokers and non-diabetics, in agreement with the literature ${ }^{5,7}$. Since that, our patients are enrolled in a service that assists patients with HIV/AIDS in becoming oriented about the disease, moreover evaluates and oriented patients for other comorbid health outcomes, we believe that these may explain the low prevalence of hypertension and diabetes found in our study among smokers. HIV/AIDS patients are exposed to accelerated aging due to the chronic inflammatory process, even if the disease is in control ${ }^{8}$ ${ }^{11}$. This inflammatory process related to ART use increases the incidence of comorbidities that are not associated with immunosuppression but are related to accelerated aging. Therefore, we consider that smoking associated with HIV infection can lead to the worsen of these diseases, and a significant worsening of comorbidities since smoking itself is the main risk factor for cardiovascular diseases and their complications ${ }^{24-25}$.

In our study, smoking was associated with malnutrition and lower scores of BMI. In HIV infection, weight loss is common and is associated with increased mortality ${ }^{26}$. Malnutrition among HIV-positive patients who smoke may be related to the fact that smokers have a lower appetite and that smoking disrupts the body's natural energy balance ${ }^{27,28}$. Our results were consistent with findings of the previous studies that show a higher prevalence of malnutrition in patients with HIV/AIDS ${ }^{27,28}$. A study conducted in Singapore showed that patients with a BMI less than 18.5 were 1.4 times more likely to die early compared to patients with a BMI higher than or equal to $18.5 \mathrm{~kg} / \mathrm{m}^{2}$, suggesting that malnutrition it is associated with lower survival ${ }^{29}$. Therefore, both smoking and malnutrition and are factors that can affect the survival status and quality of life among people living with HIV.

Regarding the skeletal mass index, a lower score was found among the smokers patients with HIV/AIDS have a loss of muscle mass typically observed in older people, probably due to a constant state of infection and long-term use of antiretroviral drugs ${ }^{9,30}$. Rom et al. demonstrated that smokers aged over 45 years with lower appendicular skeletal muscle mass are more likely to develop sarcopenia than individuals who never smoked, regardless of $\operatorname{sex}^{31}$. Currently, ART includes some drugs related to mitochondrial dysfunction that causes damage to muscle function and, consequently, changes the body composition of the patients ${ }^{28,32}$. Such dysfunction at a cellular level may explain the lower skeletal muscle mass index, which is considered indicative of sarcopenia among patients with some clinical complications. Sarcopenia has been understood as the center of the etiology of frailty that precedes physical deterioration and causes the loss of the skeletal muscle mass and its function ${ }^{16,33}$.

Our findings also revealed that HIV/AIDS patients who smoke had more prevalence of mal- 
nutrition, lower body mass index, and a tendency for lower skeletal muscle mass index. However, such findings should be considered within some limitations. Our study did not evaluate the smoking load of the patients, which prevented us from having a dose-response evaluation of smoking on this outcome. In addition, the patients are enrolled in a service that assists patients with HIV/ AIDS in becoming oriented about the disease and the importance of adherence to ART; the service also evaluates patients for other comorbid health outcomes. Moreover, a non-probabilistic sample selection was performed, which may influence the prevalence of smoking and body compo- sition measurements. Thus, the results of our study may represent the reality of medical care in this specialized service where the HIV/AIDS patient is inserted and cannot be generalized to other populations.

In conclusion, this study suggests that smoking is a risk factor for a majority of comorbidities associated with HIV/AIDS patients in the post-ART, including malnutrition and skeletal muscle mass. As tobacco has a significant impact on quality of life, morbidity, and mortality in HIV-infected patients, it seems prudent to implement actions in health public that support smoking cessation.

\section{Collaborations}

The initial project design, data collection and manuscript writing were made mainly by LGH Real, while the contributions to the methodology and statistical analysis were made similarly by the four authors. FP Moreira, K Jansen and MC Gonzalez participated in the critical review of the content and final approval of the version to be published. 


\section{References}

1. Centers for Disease Control and Prevention C. The Health consequences of smoking - 50 years of progress: $a$ report of the surgeon general. Atlanta: US Department of Health and Human Services, Centers for Disease Control and Prevention, National Center for Chronic Disease Prevention and Health Promotion, Office on Smoking and Health 2017 [cited 2018 Jan 24]. Available from: https://www.ncbi.nlm.nih.gov/books/NBK 179276/

2. Batista J, Albuquerque MFM, Ximenes RA, MirandaFilho DB, Melo HRL, Maruza M, Moura LV, Pinto da Costa Ferraz EJ, Rodrigues LC. Prevalence and socioeconomic factors associated with smoking in people living with HIV by sex, in Recife, Brazil. Rev Bras Epidemiol 2013; 16(2):432-443.

3. Torres TS, Luz PM, Derrico M, Velasquez L, Grinsztejn E, Veloso VG, Cardoso SW, Santini-Oliveira M, Grinsztejn B, De Boni RB. Factors associated with tobacco smoking and cessation among HIV-infected individuals under care in Rio de Janeiro, Brazil. PLoS One 2014; 9(12):e115900.

4. Helleberg M, May MT, Ingle SM, Dabis F, Reiss P, Fatkenheuer G, Costagliola D, d'Arminio A, Cavassini M, Smith C, Justice AC, Gill J, Sterne JA, Obel N. Smoking and life expectancy among HIV-infected individuals on antiretroviral therapy in Europe and North America. AIDS 2015; 29(2):221-229.

5. Hasse B, Tarr PE, Marques-Vidal P, Waeber G, Preisig M, Mooser V, Valeri F, Djalali S, Andri R, Bernasconi E, Calmy A, Cavassini M, Vernazza P, Battegay M, Weber R, Senn O, Vollenweider P, Ledergerber B; CoLaus Cohort, FIRE and the Swiss HIV Cohort Study, Aubert V, Barth J, Battegay M, Bernasconi E, Böni J, Bucher HC, Burton-Jeangros C, Calmy A, Cavassini M, Egger M, Elzi L, Fehr J, Fellay J, Furrer H, Fux CA, Gorgievski M, Günthard H, Haerry D, Hasse B, Hirsch HH, Hösli I, Kahlert C, Kaiser L, Keiser O, Klimkait T, Kouyos R, Kovari H, Ledergerber B, Martinetti G, Martinez de Tejada B, Metzner K, Müller N, Nadal D, Pantaleo G, Rauch A, Regenass S, Rickenbach M, Rudin C, Schöni-Affolter F, Schmid P, Schultze D, Schüpbach J, Speck R, Staehelin C, Tarr P, Telenti A, Trkola A, Vernazza P, Weber R, Yerly S, Jean-Michel A, Murielle B, Jean Michel G, Christoph H, Thomas L, Pedro MV, Vincent M, Fred P, Martin P, Peter V, Roland VK, Aidacic V, Gerard W, Jürg B, Markus B, Heinz B, Martin B, Hans-Ulrich B, Ivo B, Reto C, Isabelle C, Corinne C, Sima D, Peter D, Simone E, Andrea F, Markus F, Claudius F, Jakob F, Ali GM, Matthias G, Denis H, Marcel H, Walter H, Simon H, Felix H, Paul H, Eva K, Vladimir K, Daniel K, Stephan K, Beat K, Benedict K, Heidi K, Vesna L, Giovanni L, Werner LH, Phillippe L, Severin L, Christoph M, Jürgen M, Damian M, Werner M, Titus M, Valentina N, Jakob R, Thomas R, Hana S, Frank S, Georg S, Oliver S, Pietro $S$, Jacques $S$, Alfred S, Alois S, Claudia S, Othmar S, Phuoc TT, Marco V, Alessandro V, René VA, Hans W, Fritz W, Johanna WS, Joseph W, Marco Z. Strong impact of smoking on multimorbidity and cardiovascular risk among human immunodeficiency virus -infected individuals in comparison with the general population. Open Forum Infect Dis 2015; 2(3):ofv108.
6. Wooten D, Karris MY. The As and Bs of HIV and hepatitis co-infection. Trop Med Infect Dis 2019; 4(2):55.

7. Guaraldi G, Orlando G, Zona S, Menozzi M, Carli F, Garlassi E, Berti A, Rossi E, Roverato A, Palella F. Premature age-related comorbidities among HIV-infected persons compared with the general population. Clin Infect Dis 2011; 53(11):1120-1126.

8. Torres TS, Luz PM, Derrico M, Velasque L, Grinsztejn E, Veloso VG, Cardoso SW, Santini-Oliveira M, Grinsztejn B, De Boni RB. Factors associated with tobacco smoking and cessation among HIV-infected individuals under care in Rio de Janeiro, Brazil. PLoS One 2014; 9(12):e115900.

9. Farinatti P, Paes L, Harris EA, Lopes GO, Borges JP. A simple model to identify risk of sarcopenia and physical disability in HIV-infected patients. J Strength Cond Res 2017; 31(9):2542-2551.

10. Pinto Neto LF, Sales MC, Scaramussa ES, da Paz CJ, Morelato RL. Human immunodeficiency virus infection and its association with sarcopenia. Braz J Infect Dis 2016; 20(1):99-102.

11. Hawkins KL, Brown TT, Margolick JB, Erlandson KM. Geriatric syndromes: new frontiers in HIV and sarcopenia. AIDS 2017; 31(Supl. 2):S137-S146.

12. Singhania R, Kotler DP. Lipodystrophy in HIV patients: its challenges and management approach. HIV AIDS (Auckl) 2011; 3:135-143.

13. Alves MD, Brites C, Sprinz E. HIV-associated lipodystrophy: a review from a Brazilian perspective. Ther Clin Risk Manag 2014; 10:559-566.

14. Lee JS, Auyeung TW, Kwok T, Lau EM, Leung PC, Woo $\mathrm{J}$. Associated factors and health impact of sarcopenia in older chinese men and women: a cross-sectional study. Gerontology 2007; 53(6):404-410.

15. Hawkins KL, Zhang L, Ng DK, Althoff KN, Palella FJ Jr, Kingsley LA, Jacobson LP, Margolick JB, Lake JE, Brown TT, Erlandson KM. Abdominal obesity, sarcopenia, and osteoporosis are associated with frailty in men living with and without HIV. AIDS 2018; 32(10):1257-1266.

16. Gonzalez MC, Heymsfield SB. Bioelectrical impedance analysis for diagnosing sarcopenia and cachexia: what are we really estimating? J Cachexia Sarcopenia Muscle 2017; 8(2):187-189.

17. Kiefer E, Hoover DR, Shi Q, Dusingize JC, Cohen M, Mutimura E, Anastos K. Association of pre-treatment nutritional status with change in CD4 count after antiretroviral therapy at 6,12 , and 24 months in rwandan women. PLoS One 2011; 6(12):e29625.

18. Hong H, Budhathoki C, Farley JE. Effectiveness of macronutrient supplementation on nutritional status and HIV/AIDS progression: A systematic review and meta-analysis. Clin Nutr ESPEN 2018; 27:66-74.

19. Henrique IF, De Micheli D, Lacerda RB, Lacerda LA, Formigoni ML. Validation of the brazilian version of alcohol, smoking and substance involvement screening test (ASSIST). Rev Assoc Med Bras 2004; 50(2):199-206.

20. World Health Organization (WHO). Waist circumference and waist-hip ratio, Report of a WHO Expert Consultation, World Health Organization. Geneva: WHO; 2008. 
21. Janssen I, Heymsfield SB, Baumgartner RN, Ross R. Estimation of skeletal muscle mass by bioelectrical impedance analysis. J Appl Physiol 2000; 89(2):465471.

22. Janssen I, Baumgartner RN, Ross R, Rosenberg IH, Roubenoff R. Skeletal muscle cutpoints associated with elevated physical disability risk in older men and women. Am J Epidemiol 2004; 159(4):413-421.

23. Mdodo R, Frazier EL, Dube SR, Mattson CL, Sutton MY, Brooks JT, Skarbinski J. Cigarette smoking prevalence among adults with HIV compared with the general adult population in the United States: cross-sectional surveys. Ann Intern Med 2015; 162(5):335-344.

24. Bekele T, Rueda S, Gardner S, Raboud J, Smieja M, Kennedy R, Fletcher D, Burchell AN, Bacon J, Rourke SB. Trends and Correlates of Cigarette Smoking and Its Impacts on Health-Related Quality of Life Among People Living with HIV: Findings from the Ontario HIV Treatment Network Cohort Study, 2008-2014. AIDS Patient Care STDS 2017; 31(2):49-59.

25. Mdege ND, Shah S, Ayo-Yusuf OA, Hakim J, Siddiqi K. Tobacco use among people living with HIV: analysis of data from Demographic and Health Surveys from 28 low-income and middle-income countries. Lancet Glob Health 2017; 5(6):e578-e592.

26. Chitu-Tsu CE, Barbu EC, Lazer M, Bojinca M, Tudor AM, Hristea A, Abagiu AO, Ion AD, Badaru AI. Body composition in HIV-infected patients receiving highly active antiretroviral therapy. Acta Clin Belg 2017; 72(1):55-62.

27. Rehman AM, Woodd S, Chisenga M, Siame J, Sampson G, Praygod G, Koethe JR, Kelly P, Filteau S. Appetite testing in HIV-infected African adults recovering from malnutrition and given antiretroviral therapy. Public Health Nutr 2015; 18(4):742-751.

28. Koethe JR, Heimburger DC, PrayGod G, Filteau S. From wasting to obesity: the contribution of nutritional status to immune activation in HIV infection. $J$ Infect Dis 2016; 214(supl. 2):S75-82.
29. Palermo B, Bosch RJ, Bennett K, Jacobson JM. Body mass index and CD4+ T-lymphocyte recovery in HIV -infected men with viral suppression on antiretroviral therapy. HIV Clin Trials 2011; 12(4):222-227.

30. Echeverría P, Bonjoch A, Puig J, Estany C, Ornelas A, Clotet B, Negredo E. High Prevalence of Sarcopenia in HIV-Infected Individuals. Biomed Res Int 2018; 5074923.

31. Romeu G, Tavares M, Carmo C, Magalhães K, Nobre A, Matos V. Avaliação da adesão à terapia antirretroviral de pacientes portadores de HIV. Rev Bras Farm Hospit Serv Saude 2012; 3:37-41.

32. Wasserman P, Segal-Maurer S, Rubin DS. High prevalence of low skeletal muscle mass associated with male gender in midlife and older HIV-infected persons despite CD4 cell reconstitution and viral suppression. $J$ Int Assoc Provid AIDS Care 2014; 13(2):145-152.

33. Gonzalez MC, Heymsfield SB. Bioelectrical impedance analysis for diagnosing sarcopenia and cachexia: what are we really estimating? J Cachexia Sarcopenia Muscle 2017; 8(2):187-189.

Article submitted 11/12/2018

Approved 18/07/2019

Final version submitted 20/07/2019

Chief Editors: Romeu Gomes, Antônio Augusto Moura da Silva 